\title{
Glauber, Deus e o diabo e a questão dos gêneros cinematográficos*
}

*Esse artigo apresenta uma forma revista de um capítulo de nossa tese intitulada Deus e o Diabo na terra do sol. Uma arqueologia das imagens, defendida na PUC/SP, Programa de Comunicação e Semiótica, 1998.

JOSETTE MONZANI

Universidade Federal de São Carlos (UFSCar) 


\section{Resumo}

O artigo trata da influência do neo-realismo e do faroeste sobre Deus e o Diabo na terra do sol, de Glauber Rocha, e aponta o procedimento intertextual já presente na obra glauberiana.

\section{Palavras-chave}

Glauber Rocha, Deus e o Diabo, Gêneros Cinematográficos

\section{Abstract}

This article deals with the influence of Neo-Realism and western movies in Glauber Rocha's Deus e o Diabo na terra do sol and points to the intertextual presence in Rocha's work.

\section{Key words}

Glauber Rocha, Deus e o Diabo, Cinematographic Genres 
Mas a dificuldade não consiste em compreender que a arte grega e a epopéia estejam ligadas a certas formas do desenvolvimento social.' A dificuldade consiste em compreender como podem ainda suscitar prazer estético. E, em certa medida, serem consideradas como norma e modelos inimitaveis.

Marx

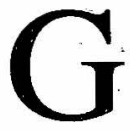
lauber é elogioso, à época da realização de Deus e o Diabo na terra do sol, com os cineastas cujas técnicas construtivas altamente pessoais, dêntro do emprego de certos gêneros cinematográficos, particularizam os filmes e criam um cinema questionador e belo: Ele parece identificar-se com esses gêneros, por colocarem em questấo algum estágio da sociedade e, simultaneamente, com os respectivos traços criativos empregados pelos cineastas, razões que podem tê-lo feito transportá-los para dentro de sua obra.

O procedimento bastante recorrente em Buñuel, conforme assinala Peñuela Cañizal (1993), é utilizado por Glauber Rocha em Deus e o Diabo. Transportamos o uso que esse autor atribui à intertextualidade $^{1}$ na obra buñuelesca a Glauber, considerando que sua utilização é marcante. Suas palavras:

$O$ talho da intertextualidade na superfície expressiva dos signos cinematográficos produz significações comprometidas, de um lado, com figuras retóricas sobre-determinadas por diferentes textos culturais associados consci-

1. Segundo a definição de Julia Kristeva: absorção e transformação de outro texto. Citada por E. P. Cañizal, O Obscuro Objeto da Ambigüidade in Um Jato na Contramão. SP, Perspectiva, 1993. P.33. 
entemente $e$, de outro, significâncias que denunciam processos simbólicos, entendido o termo psicanaliticamente, nos quais o mundo simbolizado se faz enigma. ${ }^{2}$

Queremos, neste momento, salientar procedimentos conscientes de intertextualidade. Posteriormente, construída a obra glauberiana (já que Deus e o Diabo faz parte do início da carreira de Glauber), a recorrência à intertextualidade ou intratextualidade vai se revelar, com força total, deixando ver mais algumas das fixações, das insistências, de outra natureza, do cineasta. Incluem-se neste caso a repetição de atores, por exemplo, como Geraldo del Rey, Danusa Leão, Maurício do Valle, Hugo Carvana e Othon Bastos; a escolha de atores com perfis muito determinados, caso de Tarcísio Meira, Fernando Rabal, Pierre Clementi, Antonio Pitanga e Jece Valadão; a recorrência a autores, assim como Augusto dos Anjos, poetas populares de cordel, Jorge de Lima e Mário Faustino, além da poesia popular de autoria desconhecida e de William Shakespeare; ou a repetição de temas, tais como o do dragão da maldade, das cabeças cortadas, das origens do povo brasileiro, das formas de liderança popular (inclusive a religiosa) è da representação amorosa.

\section{I- Presença do Neo-Realismo}

O Neo-Realismo permeia Deus e o Diabo. É a primeira influência sensível-no filme, posto que toda sua abertura (dos letreiros até o enterro da mãe de Manuel) está marcada por seus traços. E como Glauber consegue introduzi-lo e, depois, rompê-lo? Nossa hipótese é a de que 3 vozes narradoras operam nesta obra glauberiana, e são responsáveis pelos estilos introduzidọ.

A primeira delas, conforme apontamos em nosso livro $G \hat{e}$ nese de Deus e o Diabo na terra do sol, ${ }^{3}$ ficou estabelecida desde

2. Cañizal, E. P. O Obscuro Objeto da Ambigüidade in Um Jato na Contramão. Sāo Paulo: Perspectiva, 1993. P.33.

3. Monzani, Josette. Gênese de Deus e o Diabo na Terra do Sol. São Paulo: Annablume/Fapesp; Salvador: Fundação Gregório de Mattos e Centro de Estudos Bahianos da UFBa, 2005. 
a versão 4 do roteiro - tendo permanecido na versão-final, o filme a qual retomaremos agora, e é constituída por Manuel e Rosa.

Foram feitas alterações interessantes na versão 4 das quais decorreram consequiências importantes. A primeira diz respeito ao foco narrativo. É pela ação decisória de Manuel que a situação inicialmente se modifica. Isto já acontecia na versão 3 , diferentemente das soluções das versões 1 e 2 .

No roteiro 4, como Rosa não está implicada na decisão de Manuel, ela parte com ele, mesmo resistindo à idéia de buscar a ajuda protetora do Santo Sebastião. Manuel entrega-se a ele, assim como se entregará a Corisco (centralizando a ação novamente), e passa a vivenciar essa nova situação. Rosa é mais contida: apenas se junta aos grupos.

De início, ele (Manuel) não aceita placidamente (como ocorria nas versões anteriores do roteiro) os preceitos pietistas em sua totalidade. Acaba completamente subjugado pelo Beato e suas idéias.

Quando Manuel se torna um instrumento nas mãos do Beato, é a hora de Rosa agir. Ela, que sempre tivera dúvidas quanto à decisão de Manuel de viver naquela comunidade e não se deixara envolver pelas idéias místicas, ao ter seu marido roubado e se ver ameaçada pelo Santo, mata-o para se salvar e libertar Manuel de seu descaminho, de sua escolha.

Esta função nova, atribuída à mulher do vaqueiro, propiciou-lhe intervenção direta na trama, possibilitou a ela construir o enredo, lado a lado com Manuel. Ela deixou de ser apenas questionadora, como era anteriormente. Este traço de personalidade Rosa herdou de Maria (da versão 3 de Deus e o Diabo). Porém, Maria, era irmã do Santo. Como mulher de Manuel, é a primeira vez que ela age.

Com a morte do Beato, Manuel tem que seguir sua vida e procurar outra forma de proteção, já que não pode retroceder. Ele continua tendo esperança, acreditando na possibilidade de uma vida melhor, a partir da purificação do corpo e da alma, convicções pietistas, mesmo quando se une ao cangaceiro Corisco, por iniciativa do Cego Julio (e não sua própria). 
Dentro do cangaço, vivenciando-o, ele questiona as suas práticas. Nisto ele é auxiliado por Dada (mulher de Corisco), que tem no cansaço da luta sua razão para desejar viver em paz. Manuel, que aceitara a violência praticada pelo Beato em nome do pietismo, não vê justificativa para ela no cangaço. Rosa e Corisco são os que apóiam a vida de agressão, de guerra contra o sistema.

Percebe-se, pelo exposto acima, a primeira decorrência das modificações feitas por Glauber em seus dois últimos roteiros dessa obra: dois seres humanos comuns passaram a ser os focos principais da trama, os condutores da ação. Pelos dois 'seres humanos' estamos entendendo Manuel e Rosa, já que ela foi elevada à categoria de um dos personagens principais e condutora da ação, ao lado de Manuel. Nesta versão - a $4^{\text {a }}$. -, ela não apenas mata Sebastião como apóia o cangaço.

A muḍança de estatuto de Rosa é fato totalmente inédito. $\mathrm{O}$ vaqueiro já ocupara posição de destaque, como foco secundário da ação, nas versões 1 e 3 . $\mathrm{Na} 2$, dividia o primeiro plano com Coirana (nome do cangaceiro naquela versão).

O importante é destacar que o foco narrativo não acompanha figuras lendárias ou de liderança e sim o homem/mulher comuns, um vaqueiro e uma camponesa, trabalhadores rurais, com suas dúvidas, impulsos e crendices. Rosa e Manuel fazem o contraponto ideal um ao outro: ela é lúcida e realista, na maior parte do tempo, e contrabalança bem o misticismo e utopismo de Manuel. E isso sem ser heroína. Ele serve de freio aos impulsos dela ao introduzir "idealismo" em suas convicções.

Esse traço ativo, realista de Rosa mantém-se representado na forma narrativa. É nos momentos em que ela está presente, em cena, que a narrativà segue neo-realista, como veremos em maior detalhe. Isto até o episódio de Corisco, onde Rosà, integrada àquela realidade, modifica-se, alterando sua representação.

Os principais elementos estilísticos usados para definir o Neorealismo, estabelecidos por Borde e Bouisšy, e retomados sucintamente por Guy Hennebelle; conforme MariaRosaria Fabris aponta, ${ }^{4}$ são:

4. Fabris, M: O Neo-Realismo Cinematográfico Italiano. São Paulo: Edusp, 1996. P. 129/130. Entre colchetes aparecem comentários nossos a Deus e o Diabo, estabelecendo relação das regras com o filme. 
1) a utilização freqüente dos planos de conjunto e dos planos médios, e um enquadramento semelhante ao utilizado nos filmes de atualidades: a câmera não sugere, não disseca, só registra; [Isto é o que temos em Deus e o Diabo, aos olhos de Manuel elou Rosa] 2) a recusa dos efeitos visuais (superimpressão, imagens inclinadas, reflexos, deformações, elipses), caros ao cinema mudo: o neo-realismo - se quisermos forçar um pouco as coisas - retoma o cinema lá onde os irmãos Lumière o tinham deixado; [Há trechos onde, propositalmente, há este trabalho visual. Isso ocorre, obviamente, quando não é o neo-realismo o gênero em menção] 3) uma imagem acinzentada, segundo a tradição do documentário; 4) uma montagem sem efeitos particulares, como convém a um cinema não tão acentuadamente polêmico ou revolucionário; [Como veremos, a imagem é muitas vezes acinzentada (apesar de Glauber negar isto) e os efeitos visuais irão sendo introduzidos gradativamente em Deus e o Diabo] 5) a filmagem em cenários reais; 6) uma certa flexibilidade na decupagem, implicando um recurso freqüente à improvisação, como decorrência da utilização de cenários reais; [Recursos mantidos por Glauber. A câmera tem que 'corrigir' a imagem muitas vezes]. 7) a utilização de atores eventualmente não-profissionais, sem esquecer, no entanto, que o neo-realismo se valeu de intérpretes famosos como Lucia Bosè, Aldo Fabrizi, Vittorio Gassman, Massimo Girotti, Gina Lollobrigida, Sofia Loren, Folco Lulli, Anna Magnani, Silvana Mangano, Giulietta Masina, Amedeo Nazzari, Alberto Sordi, Paolo Stoppa, Raf Vallone e Elena Varzi, só para citarmos os italianos; [Exatamente como ocorre em Deus e o Diabo] 8) a simplicidade dos diálogos e a valorização dos dialetos, que levou diretores como Visconti e Emmer a usá-los, na ilusão de transmitir ao público uma imagem verdadeira da Itália, sem intermediários, sem tradução [recurso freqüente em Deus e o Diabo também] 9) a fil- 
magem de cenas sem gravação, sendo a. sincronização realizada posteriormente, : o que tornava possivel uma maior liberdade de atuação [Exatamente como no filme de Glauber, onde a fala nordestina, com seu ritmo e expressões, é seguida; além do fato de Othon Bastos haver dublado, posteriormente, o Beato, dada sua melhor interpretação e vocalização] 10) utilização de orçamentos módicos: o cinema social de alto custo não existe, caso contrário, deixa de ser social. [Caso de Deus e o Diabo, novamente, seguindo à risca o expresso no futuro manifesto A estética da fome, de Glauber]

O acompanhamento da trajetória de Manuel e Rosa é, a princípio, documental, realista. Glauber parece seguir os passos neorealistas de Rossellini, a quem admirava: "Rossellini é o primeiro cineasta a descobrir a câmera como 'instrumento de investigação e reflexão'.: Seu estilo de enquadramento, iluminação e seus tempos de montagem criaram, a partir de Roma, Cidade Aberta (1945), um novo método de fazer cinema". ${ }^{5}$

A câmera é distante e esquadrinhadora, como nas primeiras imagens da terra e de Manuel, e sublinhada pela Ária das Bachianas Brasileiras no.2 para Orquestra: o Canto da Nossa Terra. Deve apontar o detalhe (como a carcaça do boi), quando necessário, para levar à revelação reflexiva.

Assistindo-se aos filmes neo-realistas, vê-se que a câmera é calma, descritiva, como em Roma, Cidade Aberta; Paisá e Alemanha, Ano Zero (e trabalha, neste último, com planos mais próximos, dada, talvez, a trama mais pessoal). Os cenários são realistas, o tom narrativo é documental.. Apesar do romance, das relações de amizade, esses dados são panos-de-fundo para o problema político: a luta dos italianos não-fascistas ou dos alemães pela reconstrução da nação e da sua dignidade. Condição temática que não escapou a Glauber.

5. Rocha, Glauber. O Século do Cinema. Rio de Janeiro: Alhambra/Embrafilme,1983. P.152. 
As histórias, no cinema italiano, têm um fundo verdadeiro e tratam do cotidiano de pessoas humildes. A luz ajuda muito no clima realista: é escura, natural, não dando margem a qualquer devaneio estético por parte do espectador. A falta de perspectivas quanto ao futuro é total - caso de Deus e o Diabo que, somente em seu final, aponta para certo otimismo - e, também, como dissemos acima, esses filmes deixam-se muitas vezes levar pelo documentarismo fotográfico. Em Glauber, esses recursos são recorrentes (apesar de misturados à câmera na mão): não há uso de rebatedores, e luzes auxiliares só aparecem em algumas poucas sequiências com interiores, como a do ataque dos cangaceiros à fazenda, por exemplo.

A despeito do crítico Alex Viany haver explicitado, conforme Fabris menciona, ${ }^{6}$ que não são recursos técnicos (tais como o uso de locais verdadeiros ou atores não-profissionais, ou pouco conhecidos), os responsáveis pelo realismo do filme, Glauber menciona a técnica rosselliniana. Concordamos com ele pois, se a técnica não é tudo, e a atitude social do criador é importante, ela faz parte da forma compositiva determinante do estilo e da mensagem. Bazin, sabiamente, valoriza também este aspecto, quando salienta que, "no caso do neo-realismo, mais do que um cinema sem atores, dever-seia falar de um cinema sem intérpretes, uma vez que a idéia de interpretação era superada graças à identificação do interprete com o personagem".?

Glauber, ao homenagear este recurso neo-realista, estabelece uma distinção na colocação de Bazin: com as escolhas de atores não-profissionais para os papéis do coronel patrão de Manuel, do padre, do Beato, do cego-cantador e dos parentes do coronel Moraes, consegue criar um cinema sem atores - formado por indivíduos que não exatamente fazem parte do universo retratado; e, pela inserção e participação de populares moradores de Monte Santo, cria o cinema sem intérpretes. De certa forma, ele constitui duas formas de negação do princípio de 'representação' da atuação fílmica.

6. Fabris, R. Nelson Pereira dos Santos. Um Olhar Neo-Realista? São Paulo: Edusp, 1994. P.66.

7. Apud Fabris, R. Op. Cit. P.192. 
Mas a fonte realista de Glauber, em nosso entender, não se esgota em Rossellini. Podemos conferir a herança de Humberto Mauro e de Nelson Pereira dos Santos, em Deus e o Diabo. Vejamos.

Conforme coloca Perdigão, ${ }^{8}$ em Deus e o Diabo "cabe distinguir uma constante, ainda que em espessura tênue, atravessando o semi-primitivo Humberto Mauro até o Nelson Pereira dos Santos de Vidas Secas - rascunhos que Deus e o Diabo põe em letra de forma e repara".

Deus e o Diabo afina-se, realmente, com Vidas Secas. Mas suas fontes são, antes de mais nada, Rio, 40 graus e Rio, Zona Norte. O primeiro fez Glauber decidir ser cineasta; por mostrar-lhe as possibilidades do cinema; o segundo norteou-o, esteticamente. ${ }^{9}$

A linguagem despojada imperava em Rio, Quarenta Graus e Rio, Zona Norte sobre a parafernália técnica. A fonte dessa simplicidade era o Neo-Realismo italiano, o que foi muito bem apontado por MariaRosaria Fabris em Nelson Pereira dos Santos - Um Olhar Neo-Realista? 10

As mesmas virtudes que Glauber saliènta com relação aos prócedimentos dos italianos, ele retoma com relação ao cinema de Nelson Pereira (e também o de Humberto Mauro - como foi mencionado por Perdigão, acima - cujo pioneirismo, em matéria de cinema artesanal, barato e com uma mensagem dignificante Glauber, muito

8. Perdigão, P. Deus e o Diabo na Terra do Sol. P.152.

9. Consideramos que, apesár do parentesco de Deus è o Diabo com Vidas Secas, a referêncià daquele se faz mais intensa com Rio, $40^{\circ}$ e Rio, Zona Norte. Glauber aponta isto em Revisão Crítica do Cinema Brasileiro, Rio de Janeiro: Civilização Brasileira, 1963, p. 83/84: No primeiro momento, diz ele "Assim como eú, naquele tempo tateando a crítica, despertei violentamente do ceticismo e me decidi a ser diretor de cinema brasileiro nos momentos que estava assistindo Rio, Quarenta Graus (...)" e, no segundo, "O filme (Rio, Zoná Norte) era revolucionário para e no cinema brasileiro. Subverteu os princípios de pròdução. (...) pegàndó gente na rua e entrando em cenários naturais. - o filme respirava os ares do movimento italiano, tinha a decisão de Rosselini, De Sica, De Santis; a técnica não era necessária, porque a verdade estava para ser mostrada e não necessitava disfarces de arcos, difusores, refletores, lentes especiais. Era possível, longe dos estúdios babilônicos, fazer-se filmes no Brasil". Era um novo jeito de fazer cinema que se reiniciava, após o 'surto' $H$. Mauro, no Brasil, e que muito inspirou Glauber.

10. São Paulo: Edusp, 1994. 
precisamente, reconhece: é preciso "estudar Mauro e neste processo repensar o cinema brasileiro, não em fórmulas de indústria, mas em termos do filme como expressão do homem". ${ }^{11}$

Para aqueles que qualificavam Mauro como 'primitivo', Glauber responde: "Se primitivo em cinema for dirigir a câmera pela intuição, antes de amordaçá-la pela razão, Jean Vigo, Robert Flaherty, Roberto Rosselini, Luis Buñuel, o hindu Ray e outros tantos, entre os maiores cineastas, são primitivos". ${ }^{12}$

Mas, como o estudo de Fabris bem demonstra, há uma diferença estilística fundamental entre os dois primeiros filmes de $\mathrm{Nel}$ son Pereira. Enquanto o primeiro é propriamente Neo-realista, o segundo inaugura o realismo-crítico no Brasil. Glauber, como aponta Fabris, também, foi um dos críticos sensíveis à mudança de perspectiva existente entre essas duas obras. Diz Fabris, em Rio, Quarenta Graus Nelson "descreve a realidade em sua imediatez, como ela se manifesta diante de seus olhos" ; ${ }^{13}$ em Rio, Zona Norte deixa claro que está presente um processo de reelaboração da história, que rompe a ilusão documental. Ele consegue uma

dimensão épica, graças ao uso do retrospecto na narração da história (cujo desfecho nos antecipa), o que lhe possibilita não só privilegiar os momentos que considera realmente importantes na vida do compositor, mas torná-los presentes, devolvendo-lhes aquela dramaticidade própria à captação de uma ação imediata. ${ }^{14}$

11. Revisão Crítica do Cinema Brasileiro. Rio de Janeiro: Civilização Brasileira, 1963 , p.25. À pág. 30 Glauber reitera o que pensa: "Quando assinalo a importância de um plano, não me aventuro no menor preciosismo formal; o que importa aí não é a qualidade da lente ou da iluminação ou os rigores da composição; é, sim, o despojamento que vem do verdadeiro artista no seu contínuo diálogo com a realidade, uma relação dialética que o leva à crítica e à prática transformadoras".

12. Ob. cit. nota 21, p.27.

13. Fabris, M. Nelson Pereira dos Santos - Um Olhar Neo-Realista? São Paulo: Edusp, 1994. P.192.

14. ob. cit., p.194. 
Glauber segue as lições do mestre. Se a linguagem em Deus e o Diabo parte do Neo-Realismo, ela vai em busca do realismo crítico (no qual não estaciona). Num processo dessemelhante ao de Nelson, desvia-se do neo-realismo, por meio de recorrências a outros métodos.

O som também é por vezes, realista. Perdigão ${ }^{15}$ desenvolve este ponto muito bem. Como ele diz, ora Glauber exaspera o som natural, como o vento e os gritos; ora abranda-o. Ou o som é realista, ou é superativado. Ora o som substitui a imagem, que é suprimida; ora acontece o inverso. Ou seja, pode-se perceber que a intenção é interpor a uma trilha realista, uma não-realista, como ocorre com relação à articulação das imagens. Enquanto Manuel e Rosa saem do pé do túmulo da mãe do vaqueiro, no final da sequiência que fecha o primeiro episódio, uma zoom se aproxima da cruz e o som da voz do Beato discursando e a música que a pontua já entram na trilha sonora, antecipando a próxima seqüência, num efeito completamente anti-natural.

Há cinco momentos de ruptura do Neo-realismo no início de Deus e o Diabo, como prenúncios da linguagem que se efetivaria mais à frente.

A segunda voz narradora é a voz onisciente, que comanda a articulação das imagens/sons dentro dos planos e a montagem destes em cadeias narrativas. Ou seja, os trabalhos de câmera e montagem nos planos - seletivos, particularizadores e elípticos - e da construção das sequências, dos episódios e da estrutura geral - regrados pela justaposição - põem às claras o ponto-de-vista exterior, o narrador que, de fora da diegese, nela atua, lado a lado com os pontos-de-vista de Manuel e Rosa.

Esta voz é responsável por três rompimentos. O primeiro deles cria uma sequiência que faz lembrar H. Mauro. É a da casa de farinha, na qual a decupagem retoma Eisenstein, que também havia impregnado Mauro: os planos são descritivos; encadeados (os movimentos são vistos daqui para lá e de lá para cá), formando um círculo

15. Deus e o Diabo na Terra do Sol. Op.cit., p.164 a 166.

Significação $30 \cdot 58$ 
(partem e terminam num primeiro plano), com uma cadência detectável (abrem-se / fecham) marcada pelo ruído do moinho, formas que fazem pensar na sua correspondência com a relação amorosa, como ocorre em Ganga Bruta, e a relação amorosa adjetivada: rude, áspera, seca, sem motivação, num processo de anamorfização fantástico, que amplia o horizonte documental:

- mãos de Manuel (PP) pegando mandioca descascada e puxandoa para perto de si, câmera vai subindo e enquadrando o seu busto (PM) sentado, ele levanta a cabeça e olha (na direção de Rosa), corte.

- Rosto suado dela (detalhe), olhos baixos, inibida, corte.

- ele ainda olhando na direção dela, ${ }^{16}$ abaixa a cabeça, câmera vai abaixando, vemos sua mão com o facão a limpar a mandioca e depois segurando-a para ser ralada (plano próximo),

- enquanto ela mexe a roda (câmera vem da mandioca a ralar até ela, que gira, pelos fios que balançam do moinho) com dificuldade (ela sua): câmera enquadra roda girando, mão dela (perfil aparece) na manivela (PP ocupa tela toda); câmera anda, rosto e corpo dela de perfil aparecem (PM), corte.

- ele, na outra extremidade; as cordas balançando no meio (PA), corte.

- ela, de frente rodando (PM), por entre a roda que gira, corte.

- ele, sentado (PM), olhando para a mandioca de frente, corte.

- câmera atrás dela (PM): plano dos dois juntos, um em cada extremidade, ${ }^{17}$ corte.

- a mandioca esmagada (primeiro plano) caindo na gamela, corte.

Waldemar Lima, fotógrafo do filme, falando a respeito das filmagens, evoca o caráter plural dos efeitos fotográficos, que fez surgir a segunda voz narradora:

16. Fica caracterizada a cumplicidade deles, por esta troca de olhares.

17. Aqui fica clara a distância e a frieza existentes entre eles. Também a passividade dele; a atitude ativa dela. 
Minhas conversas com Glauber orientavam-se, sobretudo, para a escolha da forma que iríamos dar à textura plástica do filme. (...) Glauber e eu fugíamos de tudo que tivesse a aparência de um figurativo gracioso, sem poder de comunicação. Esquematizamos o estilo que seria usado, deformando e modificando as formas clássicas de trabalho, e pondo em seu lugar elementos sentimentais e intelectuais. Tudo para não desviar o espectador para contemplações estéticas desligadás do filme. A película seria trabalhada, então, conforme as necessidades expressivas do filme. (...) Recebemos os copiões (das primeiras filmagens), e o resultado era o que esperávamos. Tudo na base das velhas fotografias de atualidade e da gravura popular. ${ }^{18}$

As palavras de Leon Hirszman acrescentam a esses dados o fato que "O cinema brasileiro (com Deus e o Diabo) sai de um tom menor realista para um cinema épico". ${ }^{19}$

O traço estilístico mencionado aproxima Deus e o Diabo da obra de Mauro. Glauber parece ter olhado atentamente para o método composicional de Ganga Bruta e nele ter se inspirado. A presença de gêneros diversos, cada qual entrando à medida que há uma solicitação dramática (expressionismo, documentário realista, western, cinema clássico russo, expressionismo e melodrama de aventuras compõem Ganga Bruta), procedimento que faz lembrar o que estamos a apontar no processo de construção do filme glauberiano. ${ }^{20}$ Rocha complementa dizendo que "todas estas visões ganham um só movimento fílmico, corporificadas por um constante elo de lirismo que é a substância da 'mise-en-scène'de Mauro", afirmação que tem correspondência com o seu fazer, que também consegue um tom único, apenas que marcado não pelo lirismo, mas pelo sobressalto.

18. Lima, Waldemar. Em Busca de uma Fotografia Participante in Deus e o Diabo na Terra do Sol. Rio de Janeiro: Civilizaçāo Brasileira, 1965. P.15 a 25.

19. Deus e o Diabo na Terra do Sol. Op. cit., p.137.

20. Rocha, Glauber. Revisão Crítica do Cinema Brasileiro. Rio de Janeiro: Civilização Brasileira, 1963, p. 28 e 29. 
Os dois outros momentos de ruptura dizem respeito à montagem, após cortes bruscos, e sem conexão causal imediata: do plano em que vemos Manuel matando um.jagunço e abraçando-se com Rosa, passamos a um primeiro plano do rosto de sua mãe morta, com súbita parada da música também. Em seguida, após a reflexão de Manuel, e a balada que narra o acontecido, outro corte e já presenciamos Manuel fincando uma cruz no túmulo da mãe, com novo silêncio.

\section{II - Mix com o Western}

O quarto momento de ruptura com o Neo-realismo acontece na participação da terceira voz narradora, representada pelo cego-cantador, o transmissor de mensagens no Nordeste, que informa a respeito das personagens e comenta a trama, voz recorrente no faroeste (de cujos elementos formais Deus e o Diabo é rico, conforme mostraremos mais à frente, tanto que terminaram por contaminar a utilização do cego, dando-lhe esta característica). O cantador aparece na feira, num traço realista de Deus e o Diabo, mas canta outras vezes, neste primeiro trecho, sem estar presente.

Esse cantador, que serve o mais das vezes de narrador off da história, traz um traço recorrente no neo-realismo de Paisà e Alemanha, Ano Zero - possuidores de narrador oral; no primeiro, esse é mais atuante, unindo os vários episodios; no segundo, introdutorio da trama, apenas. ${ }^{21}$

Em seu texto O Western - Uma Introdução ao Estudo do Gênero e o Herói ${ }^{22}$ Glauber fala: “(...) a canção agora já não está

21. No texto A Voz no Cinema: a Articulação de Corpo e Espaço, de Mary Ann Doane, in A Experiência do Cinema, org. de Ismail Xavier. Rio de Janeiro: Graal/ Embrafilme, 1983, p. 457 a 475, a autora mostra que a voz over, usada comumente em documentários, tem um traço paternal, similar à 'voz de Deus', ou seja, ela tem o poder de nos fazer acreditar no que transmite. É interessante que ela seja usada nos filmes neo-realistas, que se pretendem próximos do documental.

22. Artigo de Glauber, originalmente publicado na revista Mapa, no. 1, Salvador: ABES, 1957, transcrito em Glauber Rocha - Esse Vulcão, biografia feita por João Carlos Teixeira Gomes. Rio de Janeiro: Nova Fronteira, 1997. Pág. 588. 
nos seus lábios (lábios do cowboy); saindo da alma do herói, ganha o tempo, domina a pradaria, é uma variação ao ritmo das balas", extrato que bem aponta seu conhecimento dos diferentes empregos da balada. Do cantarolar pelo cowboy (parte da diegese), ele passou ao canto off do cantador (voz narradora), essa que é a voz presente (a maior parte do tempo) em Deus e o Diabo, onde o 'cowboy' (Antonio das Mortes / Manuel?) não canta.

O quinto momento de interrupção do Neo-realismo tem traços do faroeste também. Ele tem lugar na cavalgada dos jagunços em perseguição de Manuel, típica da luta de mocinho $\mathrm{X}$ bandidos, conseguida em mais uma intervenção do segundo narrador:

- desde o momento (na sequiência anterior) em que o Cel. bate em Manuel, começa a Dança das Bachianas no. 2 para Orquestra, que diminui na morte dos jagunços, sumindo no plano da mãe morta. Esta Dança, Lembrança do Sertão, evoca a região quente, afligida periodicamente pela seca, do interior do Nordeste, ${ }^{23}$ sendo de grande agitação.

- (câmera vai acompanhando de lado, tipo travelling, PG). Manuel é visto ao longe (PG), no seu cavalo branco; sozinho, fugindo, corte.

- Os jagunços são vistos mais de perto, de frente, sem Manuel, em cavalos pretos, corte.

- Manuel é visto chegando em casa (PG), corte.

- desmonta e Rosa sai correndo de dentro da casa para encontrá-1o (PG), corte.

$\rightarrow$ de longe, vê-se a luta: Manuel a pé, com um facão / jagunço a cavalo (câmera estaciona), o jagunço cai (PG), corte.

- os dois rolando no chão (PP); ao fundo, vê-se Rosa e a mãe sendo atacadas por outro jagunço; Rosa consegue desvencilhar-se do jagunço e correr em direção a Manuel que, de pé, mata o jagunço, com quem lutava, com um tiro;

23. A profa. de Canto Coral e Regente Lilian Zamorano Cury forneceu-nos importantes subsidios para pensarmos as Bachianas de Villa-Lobos. A ela vai aqui nosso agradecimento. 
- Rosa chega em Manuel, os dois viram-se e vêem, ao fundo, o outro jagunço esfaquear a mãe de Manuel, corte.

- jagunço vem atrás deles, é morto também por Manuel; Rosa chega novamente e o abraça, corte brusco.

- Manuel fecha os olhos da mãe morta (vê-se rosto da mãe morta e a mão de Manuel); câmera vem pela sua mão e braço, o vemos agachado, música vai sumindo, corte.

- segue...

Esse tipo de planificação aparece em muitos faroestes, como No Tempo das Diligências. Na seqüência do ataque dos índios à diligência, o ritmo é o mesmo. Como a cena é bem mais extensa (em Deus e o Diabo tem apenas 30/35 segundos; lá, 7 minutos), porque mais importante para a trama, é mais elaborada: os mocinhos são quase sempre vistos mais proximamente da câmera; os índios, mais distantes. Ou seja, vemos a sequiência do ponto de vista dos heróis. Primeiramente só vemos planos exteriores; depois, passamos a ver o interior da diligência também. A música cria o clima de excitação que uma luta requer. Os planos, naturalmente, são sempre alternados, mas aqui não ocorrem ligações entre eles que não sejam determinadas pela causalidade..Isto significa, entre outras coisas, que Glauber também não desejava 'parar' no faroeste. Esse é apenas uma passagem, não o seu fim.

O que queremos apontar é que será graças à ação destes dois narradores que o neo-realismo, instaurado pelo ponto-de-vista de Manuel e Rosa, se romperá, dando espaço a outros estilos, e possibilitando o surgimento da originalidade glauberiana.

O Neo-Realismo, se está presente de forma intensa, marcando presença, no primeiro episódio do filme, nem por isso desaparece da diegese, quando outros estilos se intensificam. Fala Glauber a esse respeito:

O filme começa como um filme normal, com uma exposição realística normal, e se desintegra à medida que a 
estória evolui: toda a linguagem do filme está ligada a toda a evolução dramática da estória. O filme se inicia claro, lúcido, objetivo, e se desenvolve em círculos de desintegração. ${ }^{24}$

O Neo-realismo retorna na subida do Monte Santo - para desaparecer na entrega de Manuel ao Beato, no ataque à vila e na procissão - e volta para mostrar a solidão de Rosa. Esta, que não se deixou envolver por Sebastião, com seu realismo, traz, para a linguagem, o neo-realismo. Com Rosa o som é local: rezas, cânticos, sinos e, off, suas conversas com Manuel, juntamente com imagens límpidas, não rebuscadas. Enquanto eles estão no Monte Santo, as aparições dela são marcadas pelo neo-realismo. Quando os beatos estão em êxtase, gritando "é a chuva de ouro...", Rosa, desesperada, é vista ao vento e, inicialmente, desfocada, dada sua proximidade da câmera e, o que aparenta ser, a imediatez da captura do momento, que não haveria possibilitado o acerto do foco.

Numa outra seqüência, quando Manuel a esbofeteia e conduz para a igreja, também o registro fotográfico é, pode-se dizer, realista (num giro, a câmera acaba por mostrar até as pedras que circundam Manuel), além do som, gerando um ar documental.

No episódio de Corisco, os planos somente mantêm o realismo ao apontarem o relacionamento de Rosa e Dadá. No restante do tempo, impera a estilização de sons/imagens (a presença dos demais narradores).

A sexualidade 'fora da norma' parece marcar o final do neorealismo no filme. Ela, que começa com o relacionamento entre Dadá e Rosa, tem seu ápice na irrupção da sexualidade de Rosa, o que vai acontecer ao lado de Corisco. Se, com Manuel, como está representada na sequiência do.moinho, ela tem uma sexualidade fria, estéril (como a situação deles, aliás), ela atravessa a assexualidade enquanto estão com Sebastião, e vai encontrar uma sexualidade quente, prazerosa, no bando do cangaceiro. O prazer marcará sua experiên-

24. Deus e o Diabo na Terra do Sol. Op. Cit., p. 139.

Significação 30 • 64 
cia com Corisco, o guerreiro com uma função fecundante. ${ }^{25}$ Neste ponto, o seu olhar realista parece perder-se. Ela se rende àquela prática, que é a prática de um outro olhar para a vida. Ela assume, pela primeira vez, a desrazão.

A partir da introdução dos reinos do Beato, de Corisco e de Antônio das Mortes, como veremos, o mundo mitológico instala-se. Glauber destaca dois momentos, dentre aqueles em que Antônio das Mortes está presente, como sendo realistas. Pensamos em não acrescentá-los às seqüências realistas do filme, dado o parentesco formal da primeira com o faroeste, e o caráter de avaliação da segunda, o que já as coloca como críticas. Aponta o diretor:

(o filme) É uma fábula: Só pára para ser realista em Antônio das Mortes; quando Antônio das Mortes se encontra com a composição dà opressão formada por aquele coronel e aquele padre; e quando conversa com o cego, fazendo uma rememoração. $O$ resto, fica tudo no terreno da lenda. Por ex.. de como Antônio das Mortes matou o Corisco, o major Rufino me contou; no roteiro ia ter uma briga; depois, resolvi optar por aquela narrativa de cego - aquela canção existe -, mostrando tudo à distância, de modo a dar um plano mitológico à estória. ${ }^{26}$

\section{II a - O faroeste além do faroeste}

Luís Carlos Maciel estabeleceu uma ponte entre Deus e o Diabo e o faroeste, e afirma "que, apesar do parentesco, a forma empregada por Glauber tem um sentido próprio, diferenciado daquele dos faroestes americanos. ${ }^{27} \mathrm{O}$ próprio Glauber estabeleceu suá recorrência à balada do faroeste em Deus e o Diabo:

25. A este respeito, ler de G. Dumézil. Mitra-Varuna. Paris: Gallimard, 1948.

26. Deus e o Diabo na Terra do Sol. Op..cit., p. 134.

27. Maciel, Luís Carlos. Dialética da Violência in Deus e o Diabo na Terra do Sol. Rio de Janeiro: Civilização Brasileira, 1965. 
para desgosto de muita gente e de você (Viany), a fita tem muita influência do Western. Tem muita coisa de John Ford, que vocês não gostam mas eu adoro, e o Antônio das Mortes é uma figura de citação fordiana mesmo: a forma de ele aparecer, a forma de ele andar, o. uso da paisagem, a aplicação da balada. ${ }^{28}$

'.. :Primeiramente, vamos às colocações de Maciel, que limpam a questão da recorrência ao faroeste. Diz ele, acertadamente:

o herói do western não triunfa porque possui as outras elogiáveis virtudes consagradas pela ética dominante, mas pura e simplesmente porque é o mais forte. Porque, em última análise, é o mais rápido e o mais certeiro no gatilho - e vence o duelo final na rua deserta. $O$ western obtém, assim, sanção plena para a violência; porque, em seu mundo, não há outra maneira de triunfar excluída a da violência. O herói vence pela força porque esta é a condição eterna da vitória - e com ele vencem, também, as virtudes da ética tradicional. A violência constitui uma parte da natureza humana e o Bem só pode triunfar se cultivá-la. $O$ western é, com toda exatidão, uma metafísica da violência. ${ }^{29}$

Já Glauber Rocha "subverte o princípio básico da metafísica da violência, ao apresentar esta última condicionada historicamente e determinada pela perspectiva fundamental da alterabilidade, que seu filme assume e expõe". ${ }^{30}$ Manuel não tem direito à escolha de seu destino. Ișto porque este é determinado pelos dominadores dos poderes sociais, os Coronéis, a Igreja e seus subordinados, no caso nordestino. Mas Deus e o Diabo aponta que a práxis coletiva da classe dominada pode alterar o contorno histórico. Manuel sozinho é

28. Deus e o Diabo na Terra do Sol. Op. cit., p. 135/136.

29. Maciel, L. C. Op. cit.P.207/208.

30. Maciel, L. C. Op.cit. P.208. 
impotente. Pode, contudo, segundo Glauber, através das lutas coletivas do pietismo e do cangaço, tentar alçar a liberdade de eleger o seu futuro, assim como o futuro de sua classe.

Ainda, o Bem e o Mal, puros, integrais, são vistos como inexistentes no filme. "Cada um é tạmbém o seu contrário", conforme coloca Maciel. "Existe o homem e sua luta, na corrente da História". ${ }^{31}$ Deus e o Diabo estaria.mais, portanto, para uma dialética da violência, dinâmịca, próxima do humanismo marxista. ${ }^{32}$

Paulo Perdigão $0^{33}$ observa a semelhança entre Deus e o Diabo e o faroeste, guardado: 0 aspecto regionalista da obra glauberiana, sem asseverar a dessemelhança mencionada por Maciel. Diz ele:

Felizmente, as modulações do western não vêm até Deus e o Diabo remover sua atmosfera claramente regional - faz muito em carregar a imagem do espaço livre $e$ os tipos que a mitomania eternizou. Os vaqueiros usam gibão e montam jumentos - mas vigora aqui, tão absorvente, a violência moral, a nostalgia, a sugestão comparativa na presença extraordinária de Antônio das Mortes e.do combate que leva o filme ao desfecho: pólos de uma recordação cristalina, e de um ilustre respeito - o do western, inspirado através de seus principais títulos: Shane, de George Stevens, $e$ Terror in a Texas Town, de Joseph H. Lewis.

31. Macièl, L. C. Op. cit..P.212.

32. (8e) Maciel, no texto aqui referido, estabelece as semelhanças e dessemelhanças entre a obra de Glauber e O Diabo e o Bom Deus, de Sartre. Ver p. 210 a 212.

Ainda, como estamos tratando também da presença do neo-realismo em Deus e o Diabo, é interessante apontar que em Alemanha, Ano Zero o destino de Mateus, como o de Manuel, segue uma lógica inexorável; é imutável. Pode haver esperança para outros, não para ele.

No final do filme, quando, após ter visto a retirada do caixão de seu pai de sua casa, ele escorrega numa calha velha, fazendo-a de escorregador de brinquedo, acreditamos (por um segundo) que sua infância é recuperável. No momento seguinte, com ele, vemos as ruínas da sua antiga residência, a decadência social e moral visualizada, enquanto um bumbo toca insistente e neryosamente, ressaltando a visão. Compreendemos, e nos desesperamos, junto com ele, que não há futuro: ele caminha até a janela e pula.

33. Perdigão, P. Op. cit. nota 16, p.155. 
Os dois exemplos por ele' dados de faroestes inspiradores de Deus e o:Diabo mostram: que 'um tipo' de faroeste chamou a atenção de Glauber, não todo e qualquer exemplo extraído desse gênero. A äfirmação de Maciel tem sua razão de ser; sua generalização parece-nòs, entrètanto, um pouco precipitada.

A estrưturação dâ personagem de Antônio das Mortes, apesar de estar cälcada em carắcterísticas regionais, é toda assemelhada à dos justiceiros dos faroestes: o chapéu, a capa escura, o gestual, a espingarda e, finalmente, um passado de pistoleiro contratado e a posse de um motor único, pessoal e inquestionável, a motivar sua vida:

Deus e o Diabo estrutura-se, através de Antônio das Mortes; pelo princípio do faroeste, segundo o próprio Glauber: "a intriga passa a obedecer (...) à linha do herói que vem de longe, vive, luta, vence problemas e parte nó fím para o mesmo 'não sei' de onde sứrgiu". ${ }^{34}$

As semelhanças visuais são fortalecidas pelo uso do $\mathrm{PG}$ para focàlizá-1o, o que o deixa em contraste com a paisagem, favorecendo a expresșão da paisagem e criando a justaposição homem/natureza hostil, típica dos faroestes também.

O seu perfil de pistoleiro é semelhante não ao de qualquer pistoleiro, mas ao de Dunson (de Rio Vermelho): mais velho, elegante, desiludido, sem passado, derrotado por antecipação, dono da verdade: "eu sou a lei!", ansiando praticar uma boa ação para desta forma se redimir; ou de Shane, melancólico e misterioso. Como estes, Antônio das Mortes faz justiça pelas próprias mãos, tem o dom de decidir o certo e o errado (sendo pago ou de graça).

Paulo Perdigão ${ }^{35}$. bem o descreve:

A solidão, a melancolia, o princípio do heroísmo como atitude militar da alma, a força física como categoria moral, a masculinidade charmosa, o passado enigmáti-

34. 'O Século do Cinema. Op. cit. P.74.

35. Perdigão, P. Western Clássico. Gênese e estrutura de 'Shane'. Porto Alegre: L\&PM, 85, p.29. 
co, o contraste entre a fidalguia $e$ a rudeza - esses os traços do aventureiro americano por excelência. Com eles se apresenta Shane, ungido pelo menino como semideus (como é visto Antônio das Mortes pelo cego cantador, por Manuel e Corisco) e; no entanto, um personagem de tragédia, acabrunhado e cansado de mortes, quase surpreso com a admiração que possa despertar.

Ainda, diz Jean-Louis Rieupeyrout, no texto clássico, sobre o faroeste:

Shane continua sendo até hoje - a encarnação ideal do westerner, vindo do horizonte, portador de uma aura de mistério que seduz as platéias lcaso de Antônio das Mortes, que justificou até a realização do Dragão da Maldade, uma 'espécie' de continuação de Deus e o Diabo], depositário de virtudes que as encantam. Mas quem será Shane realmente? Terá, com efeito, virtudes?:A ambigüidade, postulando múltiplas interpretações, vitaliza a densidade e riqueza do personagem. ${ }^{36}$

36. O Western ou O Cinema Americano por excelência. Belo Horizonte: Itatiaia, 1963.

Ainda, Antônio das Mortes é ambíguo em Deus e o Diabo. Já no Dragão da Máldade, onde reaparece, perde este caráter. Aliás,'o filme todo, apesar de alegórico, é mais definido, mais claro que Deus e o Diabo. Menos complexo, naturalmente, também.

O filme começa com Antônio das Mortes entrando em campo (da direita para a esquerda) e tiros. Em seguida, vê-se um cangaceiro morrendo. Músicà de Marlos Nobre (como no Pátio); corta som e imagem.

Vê-se o professor (Othon Bastos) falando com os alunos. O início do filme é alegórico, depois entra no realismo.

Antonio das mortes, fora o prólogo; pertence ao humano, o lado, vámos dizer, realista do filme (conversa com Mattos - veio a pedido deste; conversa com o professor, fala de Lampião e Gorisco; vê o desfile na rua). Ao se encontrar com Coirana, o cangaceiro, ao lutar com ele (numa luta que mais parece uma dança), ele atravessa para o mundo mitológico e adquire consciência dos seus erros: vê que é ideologicamente incorreto, que esteve lutando do lado errado. Beija os pés da Santa, tenta salvar Coirana, refugia-se na Igreja; mata o jagunço Mata-Vaca. 
O Bem e o Mal também aparecem em ambigüidade, em alguns faroestes, a exemplo de Deus e o Diabo. Essa não é uma característica ímpar do filme de Glauber, como quer Maciel. Aqui ele se encontra com certa tradição também.

Em No Tempo das Diligências, para ficarmos com um exemplo famoso apenas, as ambigüidades são várias: a prostituta tem mais caráter do que a Sra. que, grávida e indo em busca do marido, não deixa de sentir atração e deixar-se cortejar pelo jogador; o jogador é um apostador inveterado porém é, também, ùm cavalheiro; o banqueiro é, na verdade, um ladrão; o médico beberrão, na hora em que é necessário, salva a Sra. e o bebê; e Ringo (John Wayne) é o 'boa gente', querido por todos, filho de um homem honrado e respeitador das mulheres, inclusive a prostituta, apesar de querer matar três homens. Ele quer fazer justiça, matando três bandidos, os assassinos de seu pai e irmão, no que é apoiado por todos. Ele é o fora-da-lei estimado.

Este fator faz com que Deus e o Diabo tenha uma visão realista (porque distante do maniqueísmo), de um historicismo popular (que parte dos fatos, mas adentra as interpretações lendárias), e, por esses motivos, épica, do tema.

Mas, o cruzamento através das canções, via expressão oral, o que teria a transmitir a mais? E aí nasceu uma segunda questão, então.

Voltando às canções, ao sonoro, retomamos a afirmação de Paul Zumthor, "QQualquer que seja o poder expressivo e simbólico do olhar, o registro do visível é desprovido desta espessura concreta da voz, da tactilidade do sopro, da urgência do respiro", ${ }^{37}$ por este nos levar a pensar que, essa espessura concreta que a voz possui, no

No. Dragão ele não trem a aura mitológica de Deus e o Diabo. Ele faz as vezes de Manuel: Assiste à luta (entre o Cel. e a Santa / Santo Antão, que o apunhalam como se fosse ao dragão), mas não participa dela.

Ao final, parte para a cidade: Parece cansado, abatido, talvez por causa da consciência do seu passado. Porém, deixou de ser jagunço; tornou-se um herói justiceiro consciente. Perdeu a ambigüidade; luta agora pelo Bem.

37. Zumthor, Paul. Presence de la Voix In Écriture \& Nomadisme. Entretiens etc. Montreal: L'Hexagon, 1990. Trecho traduzido pela Profa. Jerusa Pires Ferreira. 
caso do cinema, é complementar das imagens; gerando, em conjunto, uma massa verbi-voco-visual, de cujos apelos afetivos é impossível escapar.

Glauber Rocha fala, a respeito de Deus e o Diabo: "Acabado o trabalho, pronta a montagem, restavam imagens neutras, mortas, que necessitavam da música para viver", ${ }^{38}$ afirmativa que fortalece o que exprimimos acima.

A saga de Manuel e Rosa é resumida em versos:

$1^{\circ}$. "Manuel e Rosa vivia no sertão/ trabalhando a terra com as própria mão", até que morre a mãe dele (outra canção) e eles encontram Sebastião. Em canto: "Sebastião nasceu do fogo/ (...)/ anunciando que a desgraça/ ia queimá o mundo inteiro/ mas que ele podia salvar/ quem seguisse os passos dele". Manuel e Rosa seguem o Beato. Continuando, por outra canção, depreende-se que os fiéis foram mortos por Antônio das Mortes: "Da morte do Monte Santo/ sobrou Manuel vaqueiro/ por piedade de Antônio/matador de cangaceiro". Aí eles se encontram com Corisco (outra canção) e reaparece Antônio, à caça do cangaceiro: "Andando com remorso (por causa dos beatos)/ Volta Antônio das Mortes/ vem procurando noite e dia/ Corisco de São Jorge"; até que os dois se encontram e Corisco é morto: é o duelo do Dragão da Maldade contra o Santo Guerreiro (diz o verso). Não se sabe o que acontece com Manuel e Rosa ao final. Perderam-se no espaço/tempo. O fechamento é feito de considerações, neste momento críticas, do cantador: "Tá contada a minha estória/ verdade, imaginação/ espero que o sinhô tenha tirado uma lição/ que assim mal dividido/ esse mundo anda errado/ que a terra é do homem/ não é de Deus nem do Diabo". ${ }^{39}$

As canções representam um viés narrativo, que dialoga com pelo menos mais dois: o foco narrativo orquestrado por Manuel e Rosa $^{40}$ e o ponto de vista que é construído pela câmera (que cria as

38. Rocha, Glauber. Deus e o Diabo na terra do sol. Op. Cit.

39. Deus e o Diabo na Terra do Sol. Op. cit., P.111/.114.

40. Já desenvolvemos este viés narrativo em Gênese de Deus e:o Diabo na Terra do Sol. Op. Cit., onde apontamos que a colocação de Manuel e Rosa como 
imagens) e pela montagem (que as örganiza e as articula com os sons): $O$ viés, dado pelo cancioneiro nordestino, tem seus poderes expressivos que, lembremos-nos já, são fortalecidos pelos outros dois que o complementam.

Seguindo Zumthor, mais uma vez,

A enunciação da palavra ganha por isso valor, nela mesma, de ato simbólico; graça à voz ela é exibição e dor, agressão, conquista e esperança de consumação do outro, interioridade manifesta, franqueada a necessidade de invadir psiquicamente o objeto de seu desejo: o som vocalizado vai de interior a interior, liga sem outra mediação duas existências". ${ }^{41}$

Neste caso as canções contam, dão vida à epopéia de Manuel e Rosa, com estas características: de um ponto de partida, o sertão, eles vão se enveredando para lugar nenhum, o não-lugar, o indeterminado. A temporalidade é sempre obscura, também. As únicas referências temporais são que Sebastião nasceu "no mês de fevëreiro" e que Antônio das Mortes procurou por Corisco." todo o mês de fevereiro":

Das personagens, com as quais eles vão travando contato, sabe-se pouco, e é esse pouco que as define: Sebastião é Santo e milagreiro; Antônio das Mortes, o matador de cangaceiros, sem santo padroeiro; Corisco é o Diabo, é o Corisco de São Jorge e é o Santo guerreiro.

Essa epopéia passa-se, segundo as canções, portanto, num sem tempo nem espaço, típicos do universo mítico, assim como as personagens: um Santo, um Diabo, um anti-herói, e é, como se percebe, permeada pela religiosidade:

narradores ocorre na versão 4 , implicando esta modificação no maior envolvimento emocional dos espectadores com a trama.

41. Zumthor, Paul. Op: cit. nota 38. 
Paulo Perdigão apontara no texto Ficha Filmográfica, ${ }^{42}$ a presença da narrativa mitológico-épica, reconhecidamente de herança do faroeste, trazida por recursos de imagens e sons (por ele analisados).

É um viés que recria, simbolicamente, uma situação real, que nos cerca: o homem comum é um observador (como Manuel e Rosa), passivo (deve ser salvo por um líder), não é agente da História. Sem mencionar os Coronéis, abordados pelo visual e pela palavra, a questão do direito de gerir o próprio destino é teatralizada no canto, ou melhor, no canto final. Ampliando mais o horizonte, está a se tratar ali da justiça social, do surgimento do estado de direito, numa forma primitiva de luta do Bem contra o Mal.

A voz faz com que a mensagem nos atinja no âmago, gere emoções, por nos fazer reencontrar, pelo menos momentaneamente, através da recuperação de uma situação simbólica arcaica, uma parte perdida de nosso processo de humanização.

O cantador é crítico, ao final, após a morte de Corisco e com o recomeçar de Manuel e Rosa. Isto representa a marca de um 'intervalo' ou 'interrupção' na narrativa mítica que estava a se desenrolar (com a entrada em cena de outro estilo: o neo-realista), como sucedera, visualmente, no intervalo entre o epiś́dio do Beato e o de Corisco.

Em segundo lugar ele que, até então, trabalhara a favor da linguagem mítica, entrara no 'espírito' da narrativa, precisa agora ser mostrado em sua outra faceta, distinta daquela do homem do povo, ou seja, como menos alienado do que o homem comum, traço característico dos cantadores: informador do povo, jornalista do sertão, aquele que, oralmente, nas feiras e festas, divulga as notícias.

Em terceiro lugar, Glauber consegue, com esta modificação introduzida ao final, não deixar dúvida no espectador quanto à tragédia da alienação de Manuel. Como diz Maciel, "ele é uma figura trágica, destinada fatalmente ao sacrifício". O filme confia que o povo é que irá "construir, num grande despertar coletivo, seu destino". ${ }^{43}$

42. Perdigão, Paulo. Ficha Filmográfica in Deus e o Diabo na Terra do Sol. Op. cit. 43. Maciel, L. C. Op. cit., p. 212. 
Essa:exacerbação foi, lembremo-nos aqui, segundo Glauber, sugerida a ele por Leon Hirszman, a fim de criar o patético, que choca e fáz o espectador refletir:

quero registrar isso porque uma conversa rápida, de dez minutos; que tive com o Leon, foi talvez a coisa mais fundamental para o filme. Foi ele quem me falou que a melhor forma de causar um impacto para a desalienação era: deixar as personagens naquele grau de alienação $e$ evoluir com elas até o patético, um patético que provocaria um impacto tremendo e por esse impacto criaria uma rebelião contra aquele estado de coisas, contra a alienação das personagens. Essa conversa que eu tive com o Leon foi fundamental: inclusive, fez com que eu mudasse o final do filme e adotasse mesmo uma linha de impacto total, uma linha quase patética. Eu creio que, por causa disso, todas as coisas que entraram no filmeinclusive a mistura de vários tipos de filmes, e tudo isso adquiriram um tom de unidade. ${ }^{44}$

Glauber ouvia as pessoas e fazia uso das informações obtidas desta maneira, como atestam suas palavras acima. Neste caso, a sugestão de Hirszman contribuiu para que o filme ganhasse um tom eisensteiniano, grande influência de Leon, e de grande força para a mensagem: o espectador é levado à conscientização, enquanto Manuel e Rosa não. A emoção é buscada, todo o tempo, também.

\section{II b - A penetração mais profunda do faroeste em Deus e o Diabo}

Parece-nos que Deus e o Diabo, apesar das restrições acertadamente colocadas por Maciel, não deixa de cruzar com o faroeste numa base mais profunda do que a mera coincidência de recursos sonoro-visuais, mera citação.

44. Deus e o Diabo na Terra do Sol. Op. cit., p.148. 
Primeiramente, a proximidade criada pelos recursos visuais, de Antônio das Mortes com certo tipo de pistoleiro do faroeste, é útil, por fazer dele uma personagem de perfil questionável, como são, também, pelos outros focos narrativos, os perfis do Santo e de Corisco. Perdigão apontara a inspiração de Antônio das Mortes, também, dizendo haver sido este calcado no gunfighter Wilson de Shane, ${ }^{45}$ realmente um personagem de perfil ambíguo. Poderíamos aqui lembrarmo-nos de alguns outros, comø o personagem de John Wayne em n'O tempo das Diligências.

Em segundo lugar, o uso da trilha sonora em acompanhamento de ações rápidas, aceleradas, como a da perseguição de Manuel pelos jagunços do Coronel, bastante assemelhada às canções empregadas por John Ford, por ex. (ver em No Tempo das Diligências, ou na Caravana de Bravos, as sequiências dos ataques dos índios). Segundo Glauber, o ritmo lento do western "só se agitava quando uma situação exigia: lutas, tiroteio etc.". ${ }^{\text {. }}$

Ainda, no faroeste, a música tem presença quase constante, dando um clima agitado, animado, de aventura, às sequiências. Glauber faz um uso parecido das músicas, que são numerosas, em Deus e o Diabo.

Na verdade, se voltarmos aos roteiros de Deus e o Diabo, veremos que, do 1 ao 3 , principalmente, as tramas apresentadas reproduzem estruturalmente um filme de faroeste. Traço que foi amenizado a partir do roteiro $4 .^{47}$

O faroeste era uma presença forte na cabeça de Glauber à época da criação de Deus e o Diabo. A similitude entre a paisagem do western americano - onde predomina a presença do deserto ${ }^{48}$

45. Perdigão, P. Op. cit., p.158.

46. O Século do Cinema. Op. cit. p. 46

47. Monzani, Josette. Gênese de Deus é o Diabo na Terra do Sol. Op. Cit.

48. Buscombe, Edward. Inventing Monument Valley - Nineteenth-Century Landscape Photography and the Western Film in Fugitives Images from Photography to Video. Org: Patrice Petro, Bloomington and Indianapolis, Indiana University Press, 1995. Neste texto o autor, além de apontar o deserto e os 'canyons como as paisagens mais marcantes do faroeste, comenta que Monument Valley (citado no livro Deus e o Diabo) foi colocado no mapa cultural por John Ford, quem primeiro esteve lá, em 1938, para realizar No Tempo das Diligências, e subsequentemente lá rodou mais 7 : westerns. 
e o sertão não passou despercebida a Glauber; conforme atestam os cenários do filme. Conforme Buscombe, ${ }^{49}$ a suntuósidade desta paisagem só pode ser entendida com a categoria do sublime. E, o mesmo autor, prossegue dizendo que: "in the western, that action frequently takes. the form of a journey, landscape then becomes an obstacle which has to be overcome".

Estas duas colocações, bem desenvolvidas ao longo do texto, concluem que, enxergar as próprias pequenez e finitude, frente à grandiosidade natural, ao realizar a travessia, ou seja, ao ultrapassar a nätureza;-aprènder com ela, leva à superação do julgamento pessoal.

Manuel faz uma travessia, em duas etapas: Travessia que sémpre esteve presente em todos os roteiros. Ultrapassa a natureza e ó autoritarismo decisório figurado na personagem típica desta paisagem: Antônio das Mortes, e vai aprendendo que há necessidade do exercício do direito. Tudó como ocorre num bom faroeste.

Ainda, por último, ofaroeste almeja o mesmo ideal apontado em Deus e o Diabo : a luta pela posse de terra, a distribuição da terra entre aqueles que a tornarão produtiva e útil a outros seres humanos.

As palavras de Glauber, mais uma vez, atestam seu conhecimento acerca do potencial da citação feita:

$O$ western, primeira única cristalização estético-social do cinema americano, tem na figura de John Fordo gránde responsável pela sua evolução e posterior amadurecimento. $O$ western, gênero regional dos Estados Unidos, depoimento, relatório dramatizado da grande marcha da colonização desenvolvida rumo ao interior do grande país e posteriormente da fixação social desses desbravadores, de sua adaptação humana, da sua luta contra um feudalismo que se forma rapidamente - já então uma força de domínio que encontra o combate de uma consciência que surge com os pequenos lavradores se

49. Buscombe, E. Op. cit., p.93 e seguintes. 
unindo para a defesa de seus bens - afirmou-se, primeiramente, pelo significado poético, intensidade mítica em concentração no legendário herói do bem na luta contra o mal, ética espontânea de homens rústicos. ${ }^{50}$

À maneira do faroeste, Deus e o Diabo não deixa de ter um tom 'realista', verídico. Os beatos e o banditismo realmente estão muito presentes na história do Nordeste, atualizados e gravados no imaginário popular, originados na questão da posse de terra. Toda uma literatura ensaística e ficcional, assim como o cinema, abordaram esses temas. Glauber evoca estas tradições e a elas incorporase, com Deus e o Diabo.

Glauber percebeu ou pressentiu corretamente as potencialidades contidas nestes dois gêneros: o Faroeste e o NeoRealismo, ao elaborar essa obra, e usou-as até o ponto máximo em que dariam vez e voz aos seus propósitos. Citou, ou mais, historiou a linguagem cinematográfica para com ela estabelecer, ao lado de significados e significações, significâncias emocionais e arcaicas que nos fazem ser.

\section{Bibliografia}

BOJUNGA, C. Rosa baiano in Filme Cultura. Embrafilmes, Rio de Janeiro, no. 43, jan-abr. 1984.

BUSCOMBE, E. Inventing Monument Valley - Nineteenth-Century Landscape Photography and the Western Film in Fugitives Images from Photography to Video. (Org: Patrice Petro). Bloomington and Indianapolis: Indiana University Press, 1995.

CAETANO, M.R. Cangaço. O Nordestern no cinema brasileiro. Brasília: Avathar, 2005.

50. O Século do Cinema. Op. cit. p. 73. 
DOANE, M. A. A Voz no Cinema: a Articulação de Corpo e Espaço in A Experiência do Cinema (Org.: Ismail Xavier). Rio de Janeiro: Graal/Embrafilme, 1983.

DUMÉZIL, G. Mitra-Varuna. Paris: Gallimard, 1948.

FABRIS, M. O Neo-Realismo Cinematográfico Italiano. São Paulo: Edusp, 1996.

FABRIS, R. Nelson Pereira dos Santos. Um Olhar Neo-Realista? São Paulo: Edusp, 1994.

FOHLEN, C. O faroeste. São Paulo: Cia das Letras, 1989.

HARTE, Bret. Histórias de. São Paulo: Cultrix, 1964.

MONZANI, J. Gênese de Deus e o Diabo na terra do sol. São Paulo: Annablume/Fapesp; Salvador: Fundação Gregório de Mattos e Centro de Estudos Bahianos da UFBa, 2005.

PEÑUELA CAÑIZAL, E. O Obscuro Objeto da Ambiguidade in Um Jato na Contramão. (Org. Eduardo Peñuela Cañizal). São Paulo: Perspectiva, 1993.

PERDIGÃO, P. Western clássico. Gênese e estrutura de Shane. Porto Alegre, RS: L\&PM, 1985.

RIEUPEYROUT, J-L. O Western ou O Cinema Americano por excelência. Belo Horizonte: Itatiaia, 1963.

ROCHA, G. et allii. Deus e o Diabo na terra do sol. Rio de Janeiro: Civilização Brasileira, 1965.

ROCHA, G. Revisão Crítica do Cinema Brasileiro. Rio de Janeiro: Civilização Brasileira, 1963.

ROCHA, Glauber. O Século do Cinema. Rio de Janeiro: Alhambra/ Embrafilme; 1983.

TEIXEIRA GOMES, J. C. Glauber Rocha-Esse Vulcão. Rio de Janeiro: Nova Fronteira, 1997.

ZUMTHOR, P. Presence de la Voix in Écriture \& Nomadisme. Entretiens etc. Montreal: L'Hexagon, 1990. 